\title{
A FEJLESZTÉSPOLITIKA SIKERESSÉGÉT ELŐ- SEGÍTŐ TÉNYEZŐK ÉS A KOHÉZIÓS ORSZÁGOK TAPASZTALATAI MAGYARORSZÁG SZÁMÁRA ${ }^{1}$
}

\author{
(Factors Supporting the Success of Development Policy and \\ Experiences of Cohesion Countries for Hungary)
}

\section{LÓRÁND BALÁZS}

Kulcsszavak:

fejlesztéspolitika kohéziós országok támogatások

A Európai Unió kohéziós országainak felzárkózási tapasztalatai alapján érdemes levonni a megfelelö következtetéseket Magyarország számára is: a kohéziós politika eszközrendszere mellett egyéb gazdaságpolitikai, szabályozási lépésekre és fejlesztési programokra is szükség van a sikeres felzárkózáshoz, mint például a következetes makrogazdasági stabilitást támogató költségvetési és monetáris politika folytatása; a rendelkezésre álló fejlesztési források koncentrációja; az emberi eröforrás fejlesztés elönyben részesitése; társadalmi konszenzuson alapuló struktürapolitika és hosszú távi fejlesztési stratégia végrehajtása; a bürokrácia hatékonyságának erósitése és az intézményrendszer fejlesztése.

\section{Bevezetó}

Az elmúlt évtizedekben a kohéziós politika bizonyos területeken sikereket, míg más szinteken kudarcokat ért el (Horváth 2006), mikỏzben a területi egyenlötlenségek növekedése megkérdőjelezhetetlen az Európai Unió 15 régi tagállamában. Bár számos esetben találkozhatunk sikertörténetekkel a felzárkózás területén nemzeti (pl. Írország) és regionális szinten, még mindig jelentős számú régió minősíthető sikertelennek a konvergencia szempontjából. Az EU27 országai tekintetében az EU/EK történetének eddigi legnagyobb egyenlötlenségei jelennek meg. Az EU döntéshozóinak már nem csak az észak-dél megosztottsággal kell foglalkozniuk, hanem szem elött kell tartaniuk a kelet-nyugati differenciáltságot is. Az igazi kihívást az jelenti az Unió számára, hogy egyrészt elô kellene segíteni a gazdasági növekedést és a hatékonyság erősítését, másrészt nagymértékben szükséges volna a belső kohézió erősítése. Bizonyos szempontból jó helyzetben van az EU, mivel az elmúlt 15-20 év fejlesztési programjainak gyakorlata, különösen a felzárkózó régiók tapasztalata felhasználható az újonnan csatlakozott államok esetében. Így a kohéziós politika elsô időszakára jellemző saját tapasztalatokból történő tanulás („learning by doing") helyett az új tagállamokban a régi tagországok tapasztalataiból való tanulás (,learning from others") kerülhet elötérbe (Bradley et al. 2005). Kérdés, hogy vajon a kohéziós országokban sikerrel megvalósított intézkedéseket mennyiben lehet az 
Lóránd Balázs : A fejlesztéspolitika sikerességét elősegítő tényezők és a kohéziós országok

tapasztalatai Magyarország számára. - Tér és Társadalom 23. évf. 2009/2. 213-224. p.

214 Kitekintö

TÉT XXIII. évf. 2009 a 2

ủjonnan csatlakozott országokban alkalmazni, adaptálni (Maurel 2006). Az mindenesetre biztos, hogy érdemes áttekinteni a kohéziós országok tapasztalatait, és ezek alapján megfogalmazni olyan általános elveket, amelyek a fejlesztéspolitika sikerességét biztosíthatják.

\section{A kohéziós országok tapasztalatai}

A kohéziós országok az Európai Unión belül különbözö tapasztalatokat mutatnak fel a konvergencia területén, ugyanakkor egyértelmüen bizonyitható a felzárkózás országos szinten 1986 és 2000 között. Míg a négy ország GDP-je átlagosan az EU 65\%-án állt 1986-ban, addig 1999-ben már 79\%-ra növekedett (Bocsor et al. 2000). (A konkrét növekedési rátákat lásd az 1. táblázatban.) Más elemzések szerint is az 1990-es évek során a kohéziós országoknál megfigyelhető a felzárkózás nominális és monetáris szempontból is, így a négy országból három a Gazdasági és Monetáris Unió alapitó tagja is lett, egyedül Görögország maradt le ebben a tekintetben (Rácz 2007). Sok szempontból tehát sikerként könyvelhetö el az ezen országoknak juttatott források hasznosulása.

\begin{tabular}{|c|c|c|c|c|}
\hline $\begin{array}{r}\text { A kohézi } \\
\text { The Growth Rate }\end{array}$ & $\begin{array}{r}\text { ós országok GI } \\
E U \text {-átlag } \\
\text { of the GDP of }\end{array}$ & $\begin{array}{l}\text { TÁBLÁ } \\
P \text {-jének } \\
\text { zázaléká } \\
\text { he Cohes }\end{array}$ & $\begin{array}{l}\text { AT } \\
\text { százalékos n } \\
n \text { (változás) } \\
\text { Countries I }\end{array}$ & $\begin{array}{l}\text { övekedése az } \\
\text { EU average }=10\end{array}$ \\
\hline Időszak & Görögország & Írország & Portugália & Spanyolország \\
\hline $1961-1973$ & 177 & 92 & 144 & 150 \\
\hline $1974-1985$ & 85 & 190 & 110 & 95 \\
\hline $1986-1990$ & 36 & 139 & 167 & 136 \\
\hline $1991-1995$ & 80 & 413 & 120 & 87 \\
\hline $1996-2000$ & 133 & 404 & 142 & 138 \\
\hline
\end{tabular}

Forrás: Bocsor et al. $(2000,941)$ alapján saját szerkesztés.

Kezdetben a kohéziós országok csatlakozása után a hirtelen tapasztalt nyitottság és az egyre erösödő versenyhelyzet káros következményei domináltak (kisebb visszaesés volt tapasztalható), majd a méretgazdaságosságból fakadó előnyök miatt ezek az országok is sokat profitáltak a közös piacból. A felzárkózás, vagyis a konvergencia folyamata lassú és egyenetlen volt. Csak Írország jelentett kivételt, amely 1997-re elérte az EU15 egy före jutó jövedelmi átlagát, majd tovább növekedve 2002-re az Unió négy legfejlettebb országának egyike lett (Halász et al. 2005). A kohéziós országok közül tehát egyedül Írországnak sikerült csatlakoznia a fejlettségi szempontból vezetö csoporthoz (az egy före jutó GDP vásárlóerö-paritáson mérve), a másik három ország gyengébb fejlettségi szinten maradt a 2004-es adatokat figyelembe véve (Barry 2000; Maurel 2006). Mindezekböl is egyértelmü, hogy a konvergencia megvalósulása nem tekinthetö automatikusnak (Pauker 2003). A szakirodalomban 
Lóránd Balázs : A fejlesztéspolitika sikerességét elősegítő tényezők és a kohéziós országok

tapasztalatai Magyarország számára. - Tér és Társadalom 23. évf. 2009/2. 213-224. p.

TÉT XXIII. évf. 2009 a 2

Kitekintó

215

legtöbbször Î́rország példáját emelik ki, mint amely sikeresen zárkózott fel az EUátlaghoz és bekerült a legfejlettebb államok közé.

A kohézió folyamata számos tényező együttes hatásának köszönhető, mindezek közül nehéz a Strukturális Alapok hatásának kiszürése, számszerüsítése. További fontos tényezó volt a felzárkózás kapcsán a kereskedelmi kapcsolatok bővülése, a müködő töke beáramlásának növekedése és a strukturális reformok hatása. Az országok felzárkózása ellenére a differenciáltság az adott országon belül továbbra is fennmaradt a régiók szintjén, így ezen a területen a regionális politika kevésbé tekinthető sikeresnek (Halász et al. 2005). Vagyis a felzárkózás, növekedés során itt is inkább stabilizálódtak, vagy még jobban elmélyültek a területi egyenlötlenségek, melyek mérséklése további feladatot jelent majd ezeknek az országoknak és az Európai Uniónak is.

A felzárkózás egyik fontos alapeleme volt az uniós pénzügyi transzferek megjelenése a kohéziós országokban. Az Európai Unió fontos célja, hogy a fejlettségben elmaradott tagállamok számára pénzügyi forrásokat biztosítson. Az 1990-es években az uniós támogatások a kohéziós országok éves GDP-jének 2-3\%-át jelentették, mindez a beruházások szempontjából majdnem 20\%-ot tett ki. Ebbỏl a forrásból komoly fizikai infrastruktúra-fejlesztéseket hajtottak végre ezek az országok, továbbá regionális fejlesztéseket, illetve az emberi erőforrás fejlesztését finanszírozták. Fokozatosan egyre nagyobb hangsúlyt kapott a harmadik terület, számos oktatási, képzési program valósult meg, mivel a fizikai infrastruktúra elmaradottsága mellett korábban komoly versenyhátrányt okozott a lakosság iskolázottságának és képzettségének elmaradottsága a többi EU tagállamhoz képest. A négy országon belül a legtöbb forráshoz jutó régiókban a növekedés átlagosan egy százalékponttal meghaladta a többi régió átlagos növekedési ütemét, vagyis a felzárkózás irányába történt elmozdulás. Emellett jelentősen nőtt a munka termelékenysége is az említett országokban. A leglátványosabb fejlődést a fejlesztések hatására a fizikai infrastruktúra területén érték el a kohéziós országok. A humán erőforrás, a munkaerő képzettségi színvonala az EU átlagához képest még mindig elmarad Görögországban, Spanyolországban és Portugáliában. Írország itt is kivételnek számít, mivel jelentős fejlödést tud felmutatni ezen a területen is; ahogy a tudásalapú társadalom kialakításában is ez az ország érte el a legnagyobb elörelépést. Írország egyre nagyobb összegeket költ a fejlesztéspolitikára, de ezeknek egyre kisebb részét adja az Európai Unió, például az ír GNP 6,8\%-át jelentő hároméves (2000-2002) fejlesztési programban az EU hozzájárulása már csak $0,6 \%$ volt. A három éves időszak végére a GNP a fejlesztések hatására 3\%-kal lett magasabb, mint amekkora anélkül lett volna (nettó hatás). A korábban jellemző hagyományos iparágakat megmenteni szándékozó programok helyett egyre inkább előtérbe kerültek a horizontális elv alapján felépülö fejlesztési intézkedések (és a regionális fejlesztési programok), amelyek célja az emberi erőforrás fejlesztése, a $\mathrm{K}+\mathrm{F}$ és az innováció támogatása, a tudásalapú társadalom kialakításának elősegítése volt. Összességében vizsgálva az EU támogatásait, megállapítható, hogy az EU GDP kb. 0,4\%-át költötték az említett időszakban a kohéziós politikára, ami komoly növekedés-generáló hatást tudott elérni ezekben az országokban; és olyan 
Lóránd Balázs : A fejlesztéspolitika sikerességét elősegitő tényezők és a kohéziós országok

tapasztalatai Magyarország számára. - Tér és Társadalom 23. évf. 2009/2. 213-224. p.

216 Kitekintö

TÉT XXIII. évf. $2009 \square 2$

területek finanszírozását vállalta fel részben, amelyekre a folyó kiadások terhe mellett általában nincs elegendő forrás (Palócz 2005).

A Sapir-jelentés ${ }^{2}$ a kohéziós országok felzárkózásával kapcsolatban kiemeli, hogy az adminisztráció színvonala központi befolyásoló szereppel rendelkezik nem csak az egyes régiók gazdasági növekedése kapcsán, hanem az uniós politikák szempontjából is, mivel az alacsony színvonalú adminisztrációval rendelkező térségek számára gyakran problémát okoz a fejlesztési források megfelelö felhasználása. A helyi tényezők mellett fontos befolyásoló jellegzetesség a makrogazdasági stabilitás és a megfelelö közfinanszirozási rendszer is, amelyek szintén hatással vannak egy régió felzárkózására. Görögország és Írország nem sok jelét mutatta a felzárkózásnak egészen addig, amíg mindkét országban meg nem valósították a makrogazdasági stabilizációt és a strukturális reformokat (Sapir et al. 2003). Az ír modernizációhoz például nagymértékben hozzájárultak a megfelelö politikai döntések és a magas hatékonyságú állami intézmények (Pauker 2003). Mindezek hatással voltak a külföldi tókebefektetésekre is, amelyek mindkét ország számára a felzárkózás legfontosabb tényezöjét jelentették. Írország jó példaként emelhető ki, mint olyan ország, ahol az EU-s fejlesztési forrásokat olyan iparágakba fektették, amelyek komparatív előnyökkel rendelkeznek. Ennek ellenpéldájaként említhetök azon térségek, ahol olyan $\mathrm{K}+\mathrm{F}$ intenzív szférába fektették a fejlesztési pénzeket, amelyekre a helyi lakosság képzettség szempontjából nem volt felkészülve, így nem sikerült gazdasági növekedést elöidézni (Sapir et al. 2003). Tehát a fejlesztési források mellett egyéb tényezők, a gazdaságpolitikai környezet és a külföldi befektetések is komoly szerephez jutottak a felzárkózási folyamatban.

Az egyes tagállamok számára az integrációhoz tartozás minden esetben kényszerító erőként jelentkezett, ugyanakkor a nemzeti válaszok igen eltérőek voltak, az országok szintjén (például az intézményi struktúrák kapcsán) a mai napig jellegzetes különbségeket figyelhetünk meg (Horváth 200lb). Összességében a felzárkózás szempontjából Írország és Spanyolország tekinthetố a legsikeresebbnek, ugyanakkor Görögország és Portugália kapta a legtöbb forrást az EU-tól a konvergencia beindítása érdekében (Borkó-Oszlay 2007).

\section{Magyarország lehetöségei, kilátásai}

Az EU-tagságból fakadóan a 2004-2006-os időszakra a magyar kormánynak is kötelezettsége volt, hogy hároméves fejlesztési tervet hozzon létre. A terv elkészítése komoly kihívást jelentett, mivel az államigazgatás nem volt felkészülve az EUkövetelményeknek megfelelő munkára. Az EU nem fogadta el a források elosztásának eredeti, regionális koncepcióját, ezért az öt operatív programból egyet Regionális Fejlesztés Operatív Programnak neveztek el, amely tematikus intézkedéseket tartalmazott, és ennek a programnak az irányító hatósága is országos hatáskörü intézmény lett (a Nemzeti Területfejlesztési Hivatal) (Szentes et al. 2006). A legutóbbi 
Lóránd Balázs : A fejlesztéspolitika sikerességét elősegítő tényezők és a kohéziós országok tapasztalatai Magyarország számára. - Tér és Társadalom 23. évf. 2009/2. 213-224. p.

TÉT XXIII. évf. 2009 - 2

Kitekintö

217

előcsatlakozási alapokból elsajátítható tapasztalat korlátozott, mivel azok a fejlesztési programok (PHARE, SAPARD, ISPA) kevéssé voltak hasonlatosak a nemzeti fejlesztési tervezés integrált megközelítéséhez. Ráadásul ezek nagyságrendje, illetve az újonnan csatlakozott volt szocialista országok számára nyújtott fejlesztési programok keretösszege jóval alacsonyabb volt ezen országok GDP-jében mérve, mint a korábbi csatlakozások során ilyen célra allokált források (Bradley et al. 2005). Ez az időszak mindenképpen egy nagyon fontos tanulási periódusnak minösíthetö az ország számára, ami hasznos tapasztalatokkal szolgált.

A támogatási összegek alapján megállapítható, hogy a 2004-ben csatlakozott országok GDP-jük arányában jóval kevesebb fejlesztési forráshoz jutottak, mint Spanyolország és Portugália csatlakozásukkor. Az EU-tól megszerezhető források nagyságrendje optimális esetben elérte a 1,5-2\%-ot (Erdős 2006). Így a tíz új tagállam esetén a megszerezhetố források nagysága alacsonyabb az elvártnál, éppen ezért a beavatkozások hatása a gazdasági növekedésre várhatóan csekély marad. Mindez azzal magyarázható, hogy számos aggodalom fogalmazódotł meg az új tagállamok abszorpciós képességével kapcsolatban (Bouvet 2003; Tétényi 2005). Természetesen emellett az uniós költségvetés kapcsán megjelent érdekkonfliktusok is szerepet játszottak a fejlesztési források elosztásánál.

\section{TÁBLÁZAT}

A Strukturális Alapok forrásai a hazai költségvetésben (és a GDP \%-ában) 2004-2006 között

(Subsidies of the Structural Funds in the Hungarian Budget [in HUF and in the Percentage of the GDP] in the 2004-2006 Period)

\begin{tabular}{lccc}
\hline & \multicolumn{3}{c}{ Strukturális Alapok } \\
\cline { 2 - 4 } & $\begin{array}{c}\text { Közösségi } \\
\text { támogatás }\end{array}$ & $\begin{array}{c}\text { Hazai társ- } \\
\text { finanszírozás }\end{array}$ & Összesen \\
\hline millió euró & 1996 & 700 & 2696 \\
milliárd forint* & 499 & 175 & 674 \\
elöirányzat a hazai & & & \\
költségvetésben & & 38,0 & 157,0 \\
2004 & 119,0 & 0,19 & 0,77 \\
(a GDP \%-ában) & 0,58 & 54,3 & 224,2 \\
2005 & 169,9 & 0,26 & 1,06 \\
(a GDP \%-ában) & 0,80 & 70,3 & 290,4 \\
2006 & 220,1 & 0,32 & 1,32 \\
(a GDP \%-ában) & 1,00 & & \\
\hline * 250 forint/euró árfolyamon kalkulálva. & & \\
Forrás: Voszka (2006, 18). & & & \\
\end{tabular}


Lóránd Balázs : A fejlesztéspolitika sikerességét elősegítő tényezők és a kohéziós országok

tapasztalatai Magyarország számára. - Tér és Társadalom 23. évf. 2009/2. 213-224. p.

A támogatási rendszer hazai kiépülése, amelyen belül a Strukturális Alapok és a Kohéziós Alap csak két forrásként jelenik meg, 2004-re a GDP 1,3\%-át eredményezö újraelosztáshoz vezetett Magyarországon, mindebből a Strukturális Alapok keretében érkezett közösségi támogatás $0,58 \%$-ot ${ }^{3}$ tett ki (Voszka 2006). Ez egy igen alacsony arányt jelent, még akkor is, ha 2006-ra már elérte az 1\%-ot. A 2. táblázatban az I. NFT-re vonatkozó adatok találhatók, amelyek még a tervezett kifizetések nagyságát mutatják. Dilemmát okozhat annak megítélése, hogy vajon ezek a források mennyire jelentenek elegendő fejlesztési pénzt az országnak, avagy a nemzeti jövedelemhez viszonyított arányuk alapján mennyire lesznek képesek tényleges fejlesztési, felzárkóztatási hatást gyakorolni a hazai gazdaságra, társadalomra.

\section{Az EU-s források sikeres felhasználásának kritériumai Magyarország számára}

Magyarország az Európai Unióhoz történô csatlakozása után hozzáférhetett a Strukturális Alapok és a Kohéziós Alap különböző forrásaihoz. A magyar gazdaság és társadalom számára fontos körülmény, hogy az EU milyen nagyságrendű fejlesztési forrásokat irányzott elö Magyarország számára, illetve a hozzáférés milyen feltételek mentén volt lehetséges. Továbbá szintén döntő jelentőségű az is, hogy ezek a források hatékonyan hasznosuljanak, amihez szükséges az egyes térségek (régiók) abszorpciós képességének növelése. Mindehhez megfelelő cél-, eszköz- és intézményrendszernek kellett rendelkezésre állnia. A külső tényezők leginkább adottságként kezelendők, a belső gazdasági alkalmazkodás viszont komoly feladatot jelentett, amihez stratégiára volt szükség (Losoncz 1999). Mindemellett biztos, hogy nem lehet cél önmagában a kohéziós politika támogatásainak megszerzése, ennél sokkal fontosabb, hogy a belsö eröforrások mobilizálása megtörténjen, és a régiók felkészülten vegyék fel a versenyt (Horváth 2007) a mára már közel 500 milliós népességű piacon. Amennyiben egy régió kizárólagosan az EU támogatásaitól várja a fellendülést, akkor várhatóan nem lesz képes relatív pozícióján javítani (Horváth 2004). Ezért is olyan fontos, hogy a kohéziós politika mellett milyen nemzeti programok indulnak az egyes országokban.

A hazai közvéleményben kialakult az a nézet, hogy az EU-s források várhatóan komoly növekedési többletet fognak eredményezni Magyarországon. Mindezt a különbözö modellszimulációk alá is támasztották (EC 2007). Ugyanakkor a tényleges növekedési hatást a hasznosulás hatékonysága is befolyásolni fogja, melyre hatással van számos tényező. A legtöbb ökonometriai elemzés alapján a Strukturális Alapok és a Kohéziós Alap forrásai a növekedés és felzárkózás szempontjából az elözőekkel ellentétben igencsak szerény hatást gyakorolnak a hazai gazdaságra. A kimutatható hatások nagymértékben függnek a forrásokat fogadó ország jellemzöitől (MNB 2006). „A Strukturális Alapokhoz való hozzáférés és a források hatékony felhasználásának elöfeltételeit azonban Magyarországon is meg kell teremteni." 
Lóránd Balázs : A fejlesztéspolitika sikerességét elősegítő tényezők és a kohéziós országok

tapasztalatai Magyarország számára. - Tér és Társadalom 23. évf. 2009/2. 213-224. p.

TÉT XXIII. évf. 2009 a 2

Kitekintö

219

(Horváth 2001a, 19) Emellett azt is ki kell emelni, hogy az EU törekvései önmagukban nem elégségesek a konvergencia megvalósításához, szükség van az ezeket támogató nemzeti politikákra, amelyek megfelelö környezetet teremthetnek a befektetések számára és a humán tőke növelésére (Sapir et al. 2003). Mindezekből kitünik, hogy a fejlesztési források csak szükséges, de nem elégséges összetevőjét jelentik a növekedésnek.

Magyarország sikeres felzárkózásának megvalósítása érdekében a következö szempontok a legfontosabbak:

1) Fegyelmezett gazdaságpolitika megvalósitása szükséges, ezen belül is leginkább makrogazdasági stabilitást támogató költségvetési és monetáris politikát kell folytatni, illetve a külkereskedelmi politika nyitottságát érdemes növelni. Emellett fontos szerepe van a nemzeti regionális támogatások proaktív eszközeinek is (MNB 2006). Ezek a kormányzati cselekvési programok részét kell, hogy képezzék.

2) A megfelelő prioritások érdekében történő forráskoncentráción ${ }^{4}$ elengedhetetlen (Stierle 2004; Czuriga 2008), melynek persze természetes velejárói (a Williamson hipotézis ${ }^{5}$ szerint is) az erősödő területi egyenlötlenségek. Elöször az ország felzárkóztatása lehet csak a cél, később érdemes a forrásokat inkább a regionális egyenlötlenségek mérséklésére összepontosítani ( $M N B$ 2006). A felzárkózás közben egyes tagállamokban így előfordulhat, hogy növekednek az egyenlőtlenségek, ilyenkor a nemzeti politikáknak kell enyhíteni ezeket a hatásokat (szociálpolitikai eszközök, munkaerö-piaci és bérpolitikai beavatkozások stb.) (Sapir et al. 2003). Továbbá nem érdemes a fejlesztési támogatásokból a gazdasági aktivitás egyenletes ágazati szintủ elosztásának kezdeményezése sem, mivel ez sem vezet pozitív eredményekre. Éppen ezért nem szabad mesterségesen létrehozni növekedési pólusokat, mivel így a természetes agglomerációs hatások gyengülhetnek ( $M N B$ 2006). Ehhez kapesolódik az is, hogy a Strukturális Alapok és a Kohéziós Alap nyújtotta támogatásokat érdemes minél nagyobb volumenủ projektekre költeni ${ }^{6}$, mert így a tranzakciós, adminisztrációs költségek csak kis tételt jelentenek a teljes projekten belül, nem úgy, mint a kis méretü projekteknél, ahol a kettős ellenörzés miatt indokolatlanul nagy az adminisztrációs teher (NFH 2005). Fontos tehát a piaci struktúrák erősítése, és nem érdemes mesterségesen kevésbé életképes koncentrációkat létrehozni, mivel ezek nem váltják be a hozzájuk füzött reményeket.

3) A beruházások megfelelö összetételét kell kialakítani, vagyis megfelelő egyensúlyt kell találni a fizikai infrastruktúra, az emberi erőforrások és az üzleti környezet fejlesztése között. A fizikai infrastruktúra kiépítése szükséges, de ez akár növelheti is az egyenlötlenségeket, mivel elvonhatja a meglévő termelési tényezőket a kevésbé fejlett régióktól ( $M N B$ 2006). A célterületek közül nagy jelentősége van a $\mathrm{K}+\mathrm{F}-\mathrm{nek}$, a képzett munkaerönek és az infrastruktúrának; ezeket egyidejüleg szükséges fejleszteni, hogy egyik se szabjon gátat a tudásalapú innovatív gazdasági struktúrák kialakulásának. 
Lóránd Balázs : A fejlesztéspolitika sikerességét elősegítő tényezők és a kohéziós országok

tapasztalatai Magyarország számára. - Tér és Társadalom 23. évf. 2009/2. 213-224. p.

Ugyanakkor az alapinfrastruktúra kiépítése után - az ír példát követve érdemes minél nagyobb forrásokat koncentrálni a humán erôforrás fejlesztésére (oktatás és továbbképzés) (Palócz 2005; Applica 2007). Például hasznos lehet a hátrányos helyzetú emberek bevonása a felsőoktatásba, a technológiakezelési képességek erősitése és a kutatás-intenzív humán tőke generálása (MNB 2006). A legjelentősebb eredményeket azon térségek tudják felmutatni, amelyek nem a hagyományos fizikai infrastruktúra fejlesztésére koncentráltak, hanem a modern területfejlesztési hajtóerőkre helyezték a hangsúlyt, úgy mint emberi erőforrás fejlesztése, innováció, üzleti szolgáltatások erősítése, modern iparszervezési megoldások alkalmazása (Horváth 2004). Az üzleti környezet fejlesztésének hátrányai közé sorolható a holtteher-veszteség ${ }^{7}$, a diszlokációs hatás ${ }^{8}$ és a helyettesítési hatás ${ }^{9}$. A holtteher-veszteség leginkább úgy kerülhetö el, hogyha az induló $\mathrm{KKV}$-ket, a technológiai váltást megvalósítókat, a $\mathrm{K}+\mathrm{F}$ tevékenységet végzőket és az emberi erőforrás képzését támogatják ( $M N B$ 2006). Ezen beavatkozások finanszírozása nem szoríthatja ki a hazai beruházásokat (Sapir et al. 2003). A számos terület között tehát megfelelő arányokat kell meghatározni, és mindemellett az emberi eróforrás fejlesztését (oktatás, képzés) szükséges elönyben részesíteni.

4) Az állami bürokrácia hatékonysága szintén kritikus ezen a területen (Hurst et al. 2000). A pályázati rendszerek üzemeltetése érdekében szakértelemmel rendelkezö bürokratákra van szükség. A fejlesztéspolitika hatékonyságát jelentősen limitálhatja a döntéshozási kompetenciák decentralizációja (MNB 2006). Az 1988-as reformok következményeképpen az Európai Bizottságnak nincs közvetlen ráhatása a támogatott projekt kiválasztásának folyamatára és a fejlesztések végrehajtására. A megfelelö intézményrendszer (illetve az ehhez kapcsolódó képzett szakembergárda) fontossága így központi és helyi szinten is alapvetö, mivel a fejlesztési források hatékony, gördülékeny felhasználásához, a programok végrehajtásához ez mindenképpen szükséges (Bouvet 2003; Palócz 2005). Érdemes lenne csökkenteni a bürokráciát ezen a területen is, de itt is egy trade-off-al kerülünk szembe az egyszerüség és az elszámoltathatóság kapcsán. A régiók versenyképességét továbbá jelentösen befolyásolják azok az igazgatási feltételek, amelyek jellemzőek egy adott térségre. A közigazgatás, a helyi adminisztráció mind fontos katalizátorként, moderátorként müködhet közre a helyi versenyképesség kialakításában. Ennek kapcsán érdemes lenne megvizsgálni, hogy vajon a rendszer átalakítása, modernizációja mennyiben kötódik az uniós fejlesztési támogatásokhoz, vagy inkább önállóan kellene kezelni a magyar közigazgatás modernizációjának kérdéskörét (Pálné Kovács 2007). Mindezek a tényezök az EU fejlesztési forrásainak felhasználásánál is fontosak. A strukturális politika hatékony végrehajtása érdekében szükséges a nemzeti regionális politika szervezetrendszerének korszerüsítése is (Horváth 2007). Az adminisztráció feladatai szerteágazóak egy közpolitikai rendszer működtetése során, éppen ezért hatékonyságának fontossága megkérdöjelezhetetlen. 
Lóránd Balázs : A fejlesztéspolitika sikerességét elősegítő tényezők és a kohéziós országok

tapasztalatai Magyarország számára. - Tér és Társadalom 23. évf. 2009/2. 213-224. p.

TÉT XXIII. évf. 2009 『 2

Kitekintó

221

5) Különösen fontos lenne hazánkban a konvergencia-programhoz kapcsolódó intézkedések, reformok ${ }^{10}$ és a fejlesztéspolitikai stratégia elfogadásakor társadalmi konszenzust kialakítani, mivel ekkor biztosítható a döntések végigvitele (NFH 2005). A kohéziós politika a korábbiakban csak akkor váltotta be a hozzá füzött reményeket, ha a támogatások felhasználásakor több évtizeden keresztül következetes strukturális politikát érvényesítettek az adott országban (Horváth 2004). A célrendszerek konzekvens kialakítása érdekében a legjobb, ha egy stratégia készül, amelyből mindig levezetik az aktuális fejlesztéseket, és így nem aprózódnak el ezek a források (Palócz 2005).

6) Magyarországnak a sikeres forrásfelhasználás érdekében mindenképpen meg kellett ismernie az EU bürokráciáját, fontosak a személyes kapcsolatok is, de emellett a hatalmas ismeretanyag elsajátítása is kihívást jelentett (Farkas 1997). Ez egyben egy komoly tanulási folyamatot igényelt (Kengyel 2003), amely nem ért véget a csatlakozással.

7) Az anyagi tényezökön túl más faktorok is fontos szerepet játszanak a felzárkózásban. Általában a történelemben a felzárkózás sikeréhez nagyban hozzájárult az is, hogy a nemzetközi gazdasági vagy politikai szerencse a felzárkózásra intellektuálisan felkészült társadalmat ért, éppen ezért fontos, hogy az emberi értékek fontossága is megjelenjen, még ha egy társadalom anyagiakban szegény is (Kozma 1999).

A korábban bemutatott felzárkózási sikerek (és kudarcok) kapcsán figyelembe kell venni, hogy a négy kohéziós ország fejlesztéspolitikájának eredményessége alapján néhány általános következtetés, tanulság megfogalmazható Magyarország számára is (Palócz 2005); ugyanakkor nem minden tapasztalat alkalmazható az újonnan csatlakozott országokban. Például Írország egy nagyon kis területü és népességú (3,8 millió fö) ország, amely centralizált közigazgatással rendelkezik, ezért soha nem került szembe olyan jelenségekkel, amelyek jellemzőek Lengyelországban, Romániában vagy akár Magyarországon. Ráadásul İrország már 17 éve tagja volt az EU-nak, amikor a Strukturális Alap igazán jelentős támogatásai elérték az országot, jól kiépített piacgazdasági rendszerrel rendelkezett, és az állami finanszírozású programok átláthatóságát már az EU pénzügyi támogatásai előttt is biztosították (Bradley 2005).

Az igazán hatékony eszközrendszert a különbözỏ politikák együttesen alkotják, úgy mint a befektetők és a kisvállalkozók számára vonzó gazdasági környezet kialakítása, kockázatvállalásra hajlandó vállalkozói magatartás támogatása, a helyi komparatív elönyök feltárása és kihasználása, hatékony közlekedési és távközlési infrastruktúra, jó finanszírozási lehetőségek, magasan képzett rugalmas munkaerő biztositása, a beruházás és a fogyasztás közötti megfelelő egyensúly megteremtése (Boldrin 2006). Ezek a tényezők képesek egy ország felzárkózásához hozzájárulni. 


\section{Összegzés}

A kohéziós országok gyakorlata számos jellegzetességre ráirányította a figyelmet, az ír és spanyol sikeres (illetve a görög és portugál kevésbé sikeres) felzárkózás mögötti legfontosabb tapasztalat, hogy önmagában az EU-ból érkező fejlesztési források nem elegendőek, számos országos szintủ támogató intézkedésre és megfelelő gazdaságpolitikára van szükség. Az EU fejlesztési forrásai lehetöséget adnak Magyarország számára a felzárkózásra, bár a források nagyságrendje alacsonyabb a korábban vártnál.

A bemutatott szakirodalmi vizsgálatok, elemzések tanulmányozása után kijelenthető, hogy Magyarország felzárkózása érdekében a kohéziós országok tapasztalatai alapján egyértelmủen szükség van a kohéziós politika eszközrendszere mellett egyéb gazdaságpolitikai, szabályozási lépésekre és fejlesztési programokra is, mint például a következetes makrogazdasági stabilitást támogató költségvetési és monetáris politika folytatása; a rendelkezésre álló fejlesztési források koncentrációja; az emberi erőforrás fejlesztés elönyben részesítése; társadalmi konszenzuson alapuló struktúrapolitika és hosszú távú fejlesztési stratégia végrehajtása; a bürokrácia hatékonyságának erősítése és az intézményrendszer fejlesztése. Mindezek csak együttesen lehetnek eredményesek.

\section{Jegyzetek}

${ }^{1}$ A kutatás elkészítését támogatta az Oktatási és Kulturális Minisztérium Deák Ferenc Ösztöndija.

${ }^{2}$ Az André Sapir (2003) nevével fémjelzett tanulmány, amely az Európai Bizottság felkérésére készült, az EU USA-tól való lemaradásának vizsgálata és a megfelelő megoldások felvázolása érdekében szintén számos szempontból foglalkozott a regionális politikával.

${ }^{3}$ Viszonyítási alapként említhető a kutatási és fejlesztési kiadások és a társasági adóbevétel aránya 2006ban: $0,9 \%$; illetve $1,9 \%$ (Voszka 2006).

${ }^{4}$ Az eddigiekben (2000-ig) a regionális fejlesztésekre felhasznált 250 milliárd ECU támogatás eredménye nem túl meggyôzző, mivel a területi egyenlőtlenségek kapcsán csak lassú mérséklödést tapasztalhatunk. Ennek egyik oka a támogatások szétaprózottsága (Horváth 200la).

${ }^{5}$ Megvizsgálták, hogy a Williamson hipotézishez kapcsolódóan meddig fognak nőni az egyenlőtlenségek a 2004-ben csatlakozott országok esetén. Az eredmények szerint egészen addig, amíg az ország egy före jutó GDP értéke el nem éri az EU átlag 70-75\%-át. Ez után gyorsabban fognak csökkenni a különbségek, mint ahogy egészen addig nöttek ( $M N B$ 2006).

${ }^{6}$ Mivel a támogatások felhasználásának megvan az a veszélye is, hogy hosszabb távon a gazdaság támogatástól függővé válhat. A beáramló források átmenetileg mindenképpen többlet jövedelmet okoznak, de hosszú távon nem biztos, hogy pozitiv hatásai lesznek. Ezért érdemes inkább olyan beruházásokba koncentrálni a forrásokat, amelyek képesek a gazdaság kibocsátását hosszú távon is növelni (Czuriga 2008).

${ }^{7}$ Holtteher-veszteséget jelent, ha olyan beruházás támogatására kerül sor, amely egyébként is megvalósult volna.

${ }^{8}$ Diszlokációs hatást eredményez, ha a beruházás egyébként is megvalósult volna, csak egy másik térségben.

${ }^{9}$ Helyettesítési hatásról akkor beszélhetünk, ha a támogatások nélkül egy másik vállalat valósította volna meg a beruházást.

10 A kedvezöbb növekedési pályák kialakítása érdekében szükség van átfogó, integrált strukturális reformokra is (Halmai 2009). 
Lóránd Balázs : A fejlesztéspolitika sikerességét elősegitő tényezők és a kohéziós országok tapasztalatai Magyarország számára. - Tér és Társadalom 23. évf. 2009/2. 213-224. p.

\section{Irodalom}

Applica (2007) Changing Regions - Structural Changes in the EU Regions. Final Report. Applica - The Vienna Institute for International Economic Studies, Bécs. www.ec.europa.eu/regional policy/ sources/docgener/studies/pdf/changing_regions2007.pdf

Barry, F. (2000) Convergence is not Automatic: Lessons from Ireland for Central and Eastern Europe. World Economy. 10. 1379-1394. o.

Bocsor M.-Kengyel Á.-Szücs A. (2000) A területfejlesztési politika új irányai az Európai Unióban. Közgazdasági Szemle. 11. 932-948. o.

Boldrin, M. (2006) Regional policies after the EU enlargement. - Artis, M.-Banerjee, A.-Marcellino, M. (eds.) The Central and Eastern European Countries and the European Union. Cambridge University Press, Cambridge. 365-386. o.

Borkó T.-Oszlay A. (2007) Az Európai Unió költségvetési forrásainak várható makrogazdasági és fiskális hatásai 2007-2013-ban. Munkafuizet 21. ICEG EC, Budapest. www.icegec.hu/hun/docs/ munkafuzetek/munkafuzet_21.pdf

Bouvet, F. (2003) European Union Regional Policy: Allocation Determinants and Effects on Regional Economic Growth. - Job Market Paper. www.econ.ucdavis.edu/graduate/fbouvet/job_market.pdf

Bradley, J. (2005) Promoting Cohesion in the Enlarged EU: Is there a Role for National Development Plans? - Bradley, J.-Petrakos, G.-Traistaru, I. (eds.) Integration, Growth and Cohesion in an Enlarged European Union. Springer, New York. 173-205. o.

Bradley, J.-Zaleski, J.-Zuber, P. (2005) The Role of Ex-Ante Evaluation in CEE National Development Planning - A Case Study Based on Polish Administrative Experience. - Bradley, J.-Petrakos, G.Traistaru, I. (eds.) Integration, Growth and Cohesion in an Enlarged European Union. Springer, New York. 275-311. o.

Czuriga E. (2008) Kohéziós politika Portugáliában 2007 és 2013 között. - Európai Tükör. 2. 100-111. o.

EC (2007) Gyarapodó régiók, növekvó Európa. Negyedik jelentés a gazdasági és társadalmi kohézióról. Európai Bizottság, Belgium.

Erdós T. (2006) Növekedési potenciál és gazdaságpolitika. Akadémiai Kiadó, Budapest.

Farkas B. (1997) Az EU regionális politikája a gyakorlatban. - Tér és Társadalom. 2. 55-66. o.

Halász A.-Gáspár P.-Somogyi Á. (2005) Az uniós támogatások és a gazdaság abszorpciós kapacitása. Munkafüzet 10. ICEG EC, Budapest.

Halmai P. (2009) Felzárkózás és konvergencia az Európai Unióban. - Statisztikai Szemle. 1. 41-62. o.

Horváth Gy. (2001a) Európai regionális politika. Dialóg Campus Kiadó, Budapest-Pécs.

Horváth Gy. (200lb) Regionális támogatások az Európai Unióban. Osiris Kiadó, Budapest.

Horváth Gy. (2004) Regionális egyenlötlenségek Európában. - Magyar Tudomány. 9. 962-977. o.

Horváth Gy. (2006) Differenciált kelet-közép-európai tér. Regionális teljesítőképesség és a területfejlesztés törvényi szabályozása. - Falu Város Régió. 1. 11-16. o.

Horváth Gy. (2007) A régiók Európában. - Gazdálkodás. 3. 3-14. o.

Hurst, C.-Thisse, J.F.-Vanhoudt, P. (2000) What Diagnosis for Europe's Align Regions?' - EIB Papers. 1. 9-29. o. www.eib.org/attachments/efs/eibpapers/eibpapers_2000 v05 n01/eibpapers_2000 v05_n01_a01_en.pdf

Kengyel, A. (2003) The EU's regional policy. - Palánkai, T. (szerk.) Economics of European Integration. Akadémiai Kiadó, Budapest. 355-375. o.

Kozma F. (1999) Latens fejlettség - a felzárkózás „startvonala”. - Statisztikai Szemle. 4. 242-259. o.

Losoncz M. (1999) A közösségi támogatáspolitika és Magyarország. A külső forrásbevonással szembeni követelmények. - Közgazdasági Szemle. 11. 1030-1038. o.

Maurel, M-C. (2006) Területi egyenlötlenségek Európában. A bővités, mint a kohézió próbája. - Tér és Társadalom. 4. 169-182. o.

MNB (2006) Elemzés a konvergencia-folyamatokról. Magyar Nemzeti Bank, Budapest.

NFH (2005) Kilátó. Magyarország fejlódését meghatározó nemzetközi folyamatokról - Az OFK-t megalapozó nemzetközi kitekintés - A Magyar Tudományos Akadémia véleménye és a tárcavélemények alapján átdolgozott változat. Nemzeti Fejlesztési Hivatal, Budapest.

Pálné Kovács I. (2007) Magyar területi reform és az uniós fejlesztéspolitika. - Magyar Tudomány. 10. 1306-1315. o.

Palócz É. (témavezető) (2005) A nemzetközi fejlesztéspolitikai stratégiakészités gyakorlata. KOPINTDATORG, Budapest.

Pauker Cs. (2003) Az „ír csoda” és ami mögötte van. - Barancsuk J.-Oroszi S.-Varga A. (szerk.) Tanulmánykötet Zinhober Ferenc professzor emlékére. PTE KTK, Pécs. 233-244. o. 
Rácz M. (2007) Uniós kihivások és válaszutak a 2000-es években. Az egységes belső piac és a közös pénz. Akadémiai Kiadó, Budapest.

Sapir, A.-Aghion, P.-Bertola, G.-Hellwig, M.-Pisani-Ferry, J.-Rosati, D.-Viñals, J.-Wallace, H. (2003) An Agenda for a Growing Europe. Making the EU Economic System Deliver. Report of an Independent High-Level Study Group established on the initiative of the President of the European Commission. www.euractiv.com/ndbtext/innovation/sapirreport.pdf

Stierle, M.H. (2004) Conditions for a contribution by the Structural Funds to real convergence of the Recently Acceded Member States. Paper for European Regional Science Association Conference. www.ersa.org/ersaconfs/ersa05/papers/596.pdf

Szentes T.-Bató M.-Blahó A.-Dorner A.-Kutasi G.-Magas I.-Polyánszky T.Z.-Szabó Zs.-Szajp Sz. (2006) Fejlödés, versenyképesség, globalizáció II. Akadémiai Kiadó, Budapest.

Tétényi T. (2005) A strukturális beavatkozások társfinanszírozása az új tagállamokban. Szủk keresztmetszet vagy adagolás? Elöitéletek és tények. - Sorsforditó esztendö. A 42. Közgazdász-Vándorgyủlés elöadásai. TAS $-11 \mathrm{Kft}$., Budapest. $381-407$. o.

Voszka É. (2006) Uniós támogatások - a redisztribúció új szakasza? - Külgazdaság. 6. 8-30. o. 